\title{
ANOTHER NEW SPECIES OF GIANT PITCHER PLANT FROM THE PHILIPPINES
}

Stewart McPherson • 61 Lake D rive $•$ Hamworthy • Poole • Dorset • B H 15 4LR • UK • stewart@ redfernnatural history.com

Keywords: Nepenthes palwanensis, Sultan Peak, Palawan, Philippines.

Following the discovery of Nepenthes attenboroughii on M ount Victoria, I returned to Palawan in J anuary 2010 to explore another mountain called Sultan Peak with a Filipino botanist friend. As mentioned in my article on N epenthes attenboroughii one year ago, the Philippine island of Palawan is of extreme botanical interest because it is a hotspot of diversity located close to the great island of Borneo, but it has remained relatively little explored, especially in terms of carnivorous plants.

A fter spending one week to receive permission from the provincial mayor and local authorities, I was fortunate to travel to the base of Sultan Peak and begin a climb to the summit of the mountain. Sultan Peak is located nearby M ount Victoria, but is separated by a large valley several kilometers broad. The summit is of a comparable altitude but it is ecologically isolated and so a possible home for distinct, but related highland Nepenthes flora. I arrived at the base of Sultan Peak on J anuary $17^{\text {th }}$, having previously found and engaged three hunters who would act as guides, and purchased food and provisions. The guides live in a wooden shack near to the base of Sultan Peak, however repeatedly said that, to the best of their knowledge, no person had previously climbed to the summit of the mountain. They agreed to help me climb as far up the unknown slopes as possible, but repeatedly exclaimed that they did not know whether the summit was within reach.

O ur little group left on J anuary $18^{\text {th }}$, and trekking through the lowlands we passed several hunting parties searching for pigs. Each hunting group had long wooden spears with sharpened metal points and hunting dogs. The climb up Sultan Peak was not difficult and a path existed for several kilometers up the lower slopes, but swiftly evaporated in the mayhem of rainforest vegetation. We
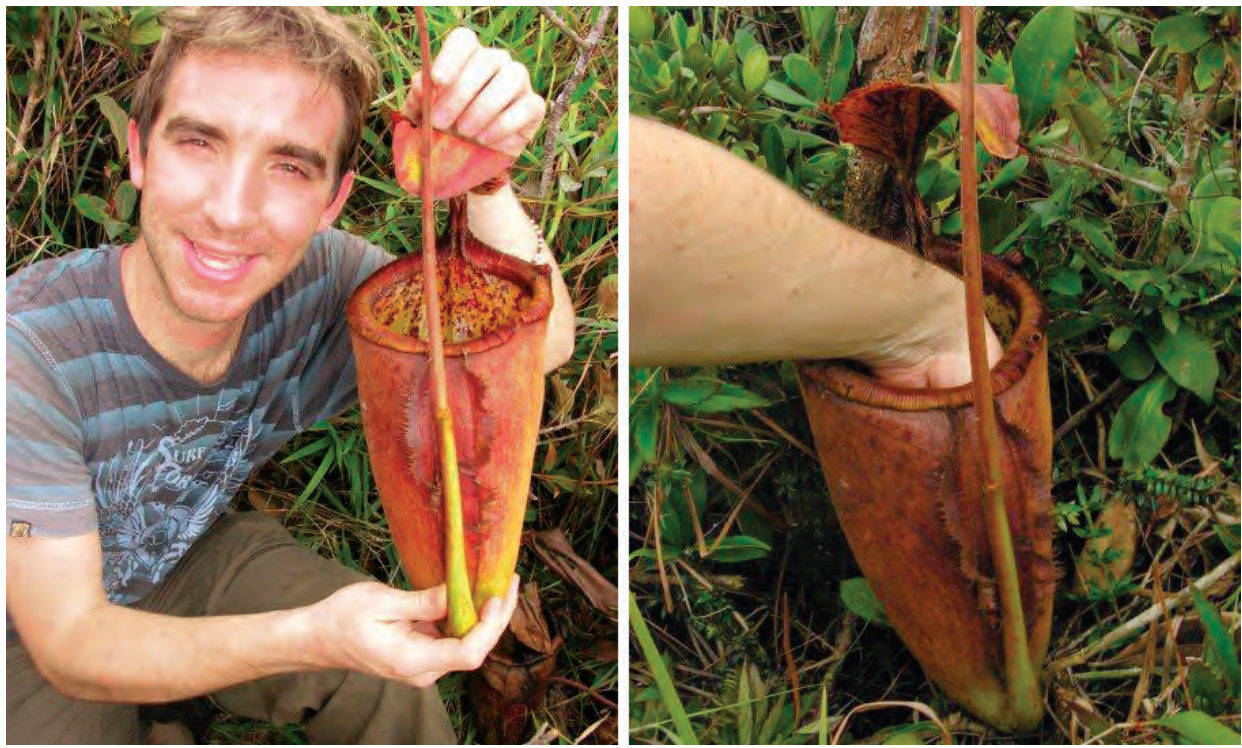

Figure 1: Stewart McPherson enjoying large Nepenthes palwanensis pitchers, Sultan Peak, Palawan, Philippines. 
could proceed only by machetteing a path forward or by following the courses of streams. After two days trekking, we reached a ledge close to a $30-\mathrm{m}$ waterfall and beheld a glorious view of M ount Victoria in the distance. This was as far as the guides had been before, and since the waterfall was nameless, we decided to call it Sultan Falls. Two of the guides looked ahead for the best direction to continue, while I hel ped establish our camp for the night.

The following morning we continued our climb, scrambling up a steep water course and climbing up several abrupt, near vertical ledges. A fter several hours we passed through bamboo forest, then upper montane scrub, and then finally we reached the summit of a ridge line a few hundred metres below the mountain top. Exactly as on M ount Victoria, as I stepped out from the bushes and small trees into open montane heath, the abrupt vegetation change brought a population of a magnificent giant $N$ epenthes plants. A fter studying the Nepenthes for a few minutes, it was apparent that the find represented a new species, although one very closely related to $\mathrm{N}$. attenboroughii.

The N epenthes of Sultan Peak bore spectacular ovate, reddish pitchers lined with short hairs (see B ack Cover). The traps are truly gigantic, I found several pitchers exceeding $35 \mathrm{~cm}$ in length, and so large that I could place my entire hand and part of my forearm inside the great traps (see Figure 1). Interestingly, all of the pitchers I observed were lower ones. M any highland Nepenthes of the Philippines are known to only produce lower pitchers (e.g. N. hamiguitanensis), however, this trait in this new taxon was in stark contrast to N. attenboroughii, which produces upper pitchers from a very early age, and all mature plants consist entirely of upper traps. Other subtle differences could be identified in the leaf structure, pitcher lid, and various other characteristics.

Continued exploration of the summit of Sultan Peak revealed that all populations of the Nepenthes occurred in direct sunlight amongst windswept, stunted, upper montane shrubs and scrub $1 \mathrm{~m}$ tall or so. M ost of the aged, mature plants had formed a rigid, upright or scrambling stem up to $1.5 \mathrm{~m}$ long and had a growing habit almost identical to N. attenboroughii. With no water source on the summit, and no rivers visible on the upper slopes, we were forced to begin our descent in the early afternoon and began trekking down the ridge top, past the scars of gigantic landslides. The following day, we returned back to civilisation, and shared all our findings with friends at the Pal awan State U niversity. We jointly decided that the plant would be named N epenthes palawanensis, since its pitchers are larger than N . attenboroughii and all other Nepenthes of Palawan, and so a fitting tribute to that beautiful Philippine isle.

A $n$ extensive account of the morphology of Nepenthes palawanensis is presented in Stewart M cPherson's new, two volume work Carnivorous Plants and their Habitats, which examines all carnivorous plant genera in the wild (see www.redfernnatural history.com for more information and also for videos and photos of Nepenthes palawanensis).

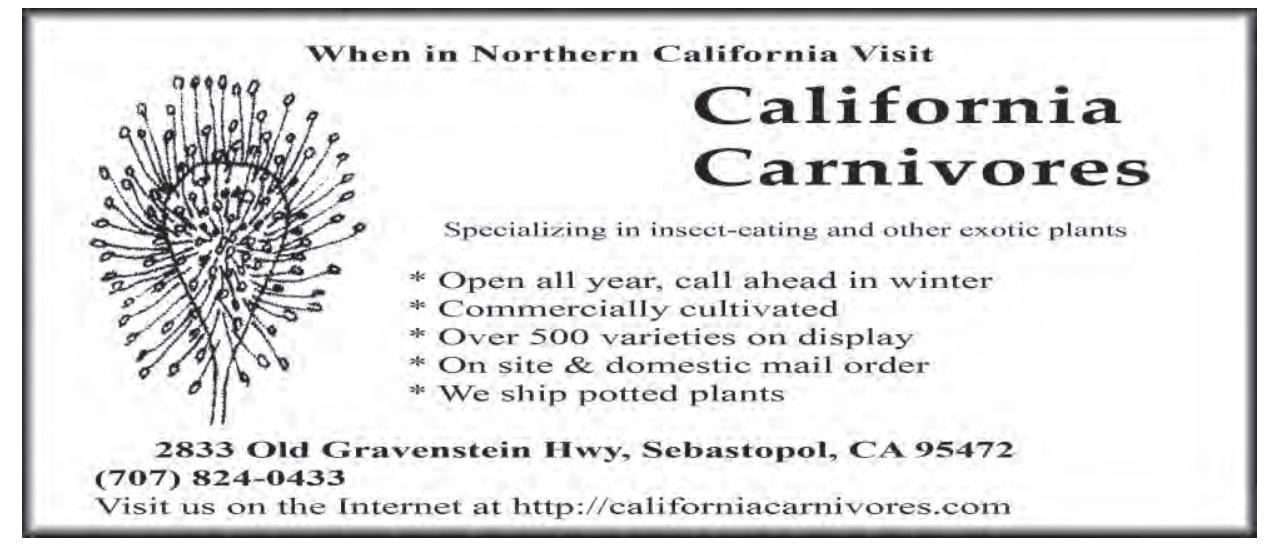




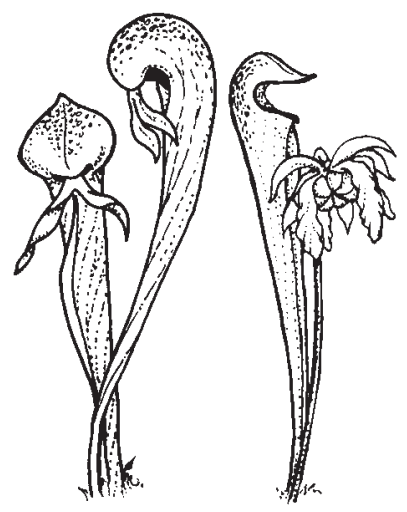

\title{
CARNIVOROUS \\ PLANT \\ NEWSLETTER
}

Journal of the International Carnivorous Plant Society www.carnivorousplants.org

\section{Volume 39, Number 3 September 2010}

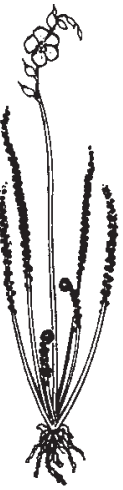

\section{Front Cover: Triphyophyllum peltatum with three glandular leaves in the greenhouse of the Botanical Gardens of Bonn. Photo by Katja Rembold. Article on page 71.}

Back Cover: A 35-cm-long pitcher of Nepenthes palawanensis, a close relative of Nepenthes attenboroughii from Palawan, Philippines. Photo by Stewart McPherson. Article on page 89.

Carnivorous Plant Newsletter is dedicated to spreading knowledge and news related to carnivorous plants. Reader contributions are essential for this mission to be successful. Do not hesitate to contact the editors with information about your plants, conservation projects, field trips, or noteworthy events. A dvertisers should contact the editors. Views expressed in this publication are those of the authors, not the editorial staff.

All correspondence regarding dues, address changes and missing issues should be sent to the Membership Coordinator at the ICPS. Do not send such correspondence to the editors. Checks for subscriptions should be made to the ICPS in US funds. Dues for 2010 are $\$ 35$ for the first year of membership; renewals are $\$ 30$ per year.

\author{
ICPS, Inc. \\ PM B 322 \\ 1564-A Fitzgerald Drive \\ Pinole, CA 94564-2229, USA \\ icps@ carnivorousplants.org
}

$\begin{array}{ll}\text { President } & \text { M ichael Baldwin, michael@ carnivorousplants.org } \\ \text { Vice President } & \text { M arcel van den B roek, marcel@ carnivorousplants.org } \\ \text { Secretary } & \text { Cindy Slezak, cindy@ carnivorousplants.org } \\ \text { Treasurer } & \text { Richard M yers, richard@ carnivorousplants.org } \\ \text { B oard M ember } & \text { B ob Ziemer, bob@ carnivorousplants.org } \\ \text { B oard M ember } & \text { Jan Schlauer, jan@ carnivorousplants.org } \\ \text { B oard M ember } & \text { B rian Barnes, Conservation Director, brian@ carnivorousplants.org } \\ \text { Seed Bank M anager } & \text { John B rittnacher, john@ carnivorousplants.org (see seed bank ad in this issue) }\end{array}$

Editors:

M anaging Editor Bob Ziemer, bob@carnivorousplants.org

Science Editor Jan Schlauer, jan@ carnivorousplants.org

Science Editor Fernando Rivadavia, fernando@ carnivorousplants.org

Editor Barry Rice, barry@ carnivorousplants.org

Date of effective publication of the June 2010 issue of Carnivorous Plant N ewsletter: 1 J une 2010.

The ICPS is the International Cultivar Registration A uthority (ICRA) for the names of cultivated carnivorous plants according to the International Code of N omenclature for Cultivated Plants. Send relevant correspondence to the ICPS, Inc.

PUBLISHER: ICPS, Inc., Pinole, California. Published quarterly with onevolumeannually. Printed by A Ilen Press, Inc., 810 E.10th Street, L awrence, K S 66044. L ogo and masthead art: Paul M ilauskas.

Dues for 2010 are $\$ 35$ for the first year of membership; renewals are $\$ 30$ per year.

(c) 2010 Carnivorous Plant N ewsletter. A II rights reserved. ISSN \#0190-9215 
(1) J (9.

y

S1

1.

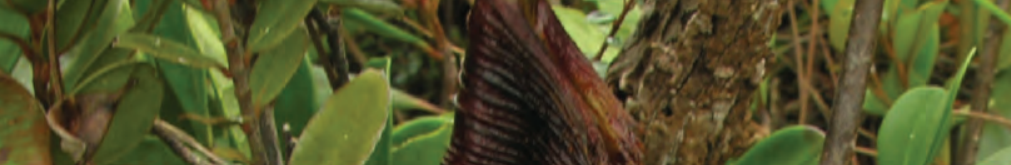

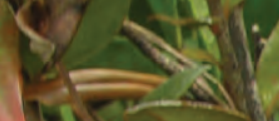

18

$\geq$

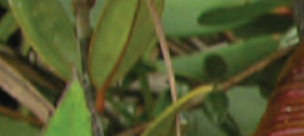
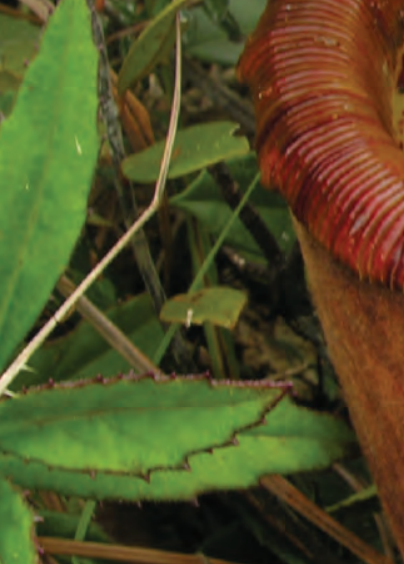

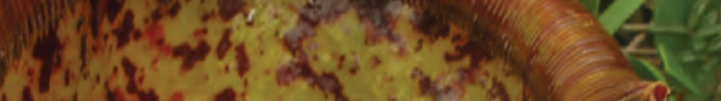

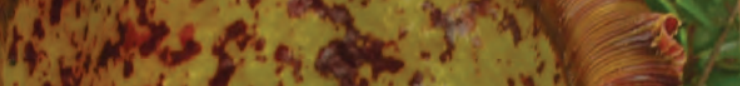
A. Hins

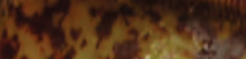
4.
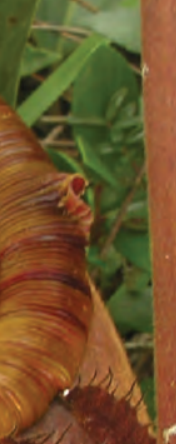
$\frac{5}{4}$

M.
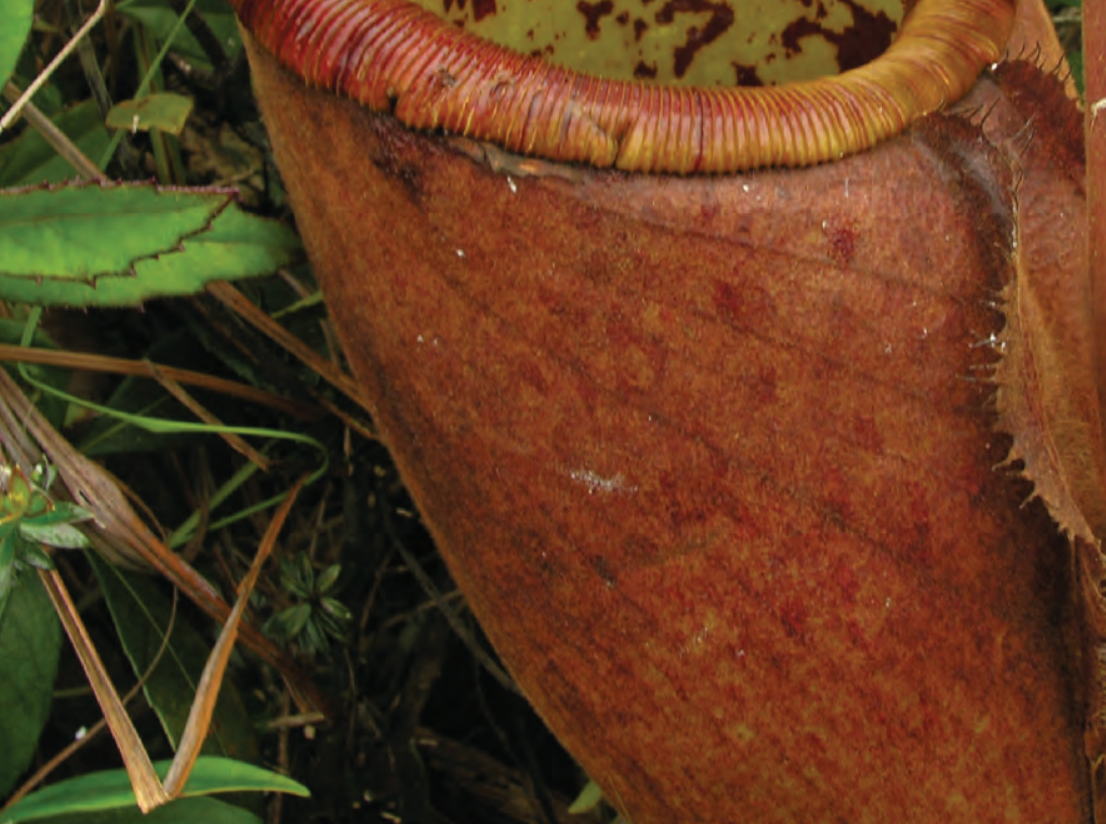

Whaterts

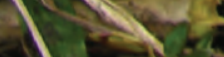

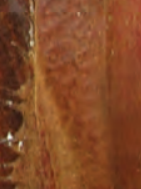
+86.

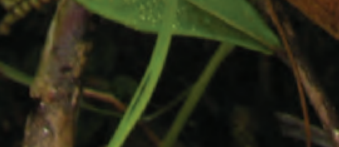

$\mid 60 /=2 \times$

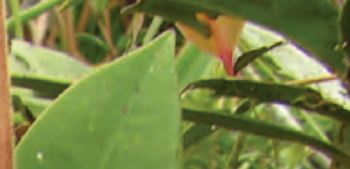
: 19 1020 \& (2) $2-20, \frac{1}{7}$

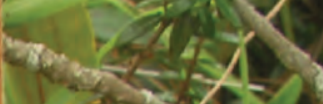
$3+2-2=2$ side?

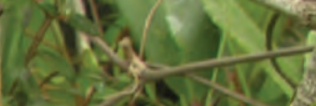

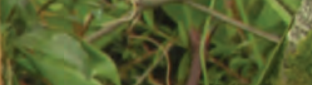

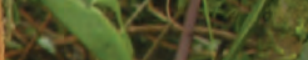

$0.3 \sqrt{2}$
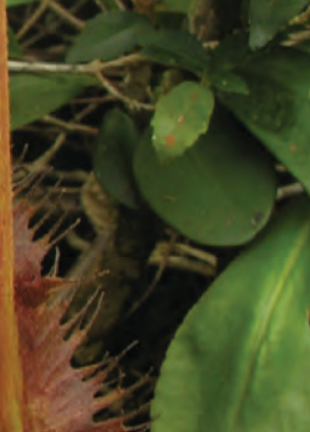

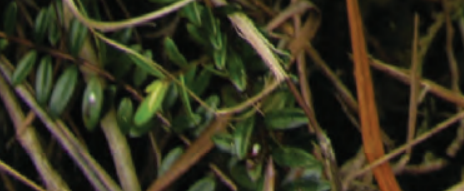

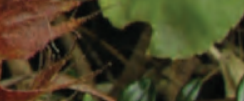
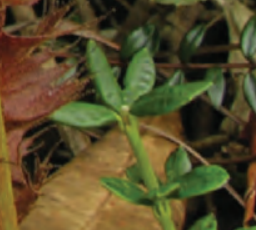

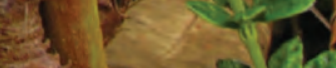
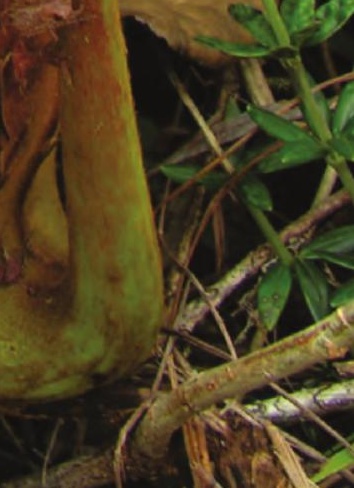
is 